Cuadernos de Gobierno y Administración Pública ISSN: e-2341-4839

http://dx.doi.org/10.5209/CGAP.60608

\title{
Institutional development and public control: Analyzing the Brazilian accountability system
}

\author{
Fernando Filgueiras*
}

Recibido: 17/12/2017 / Aceptado: 31/01/2018

\begin{abstract}
This paper aims to analyze the institutional development process of accountability institutions in Brazil. Scholars have identified an incremental development process of horizontal accountability institutions in Brazil, stimulating an important process in democracy. Our argument is that the incremental development process of accountability institutions was not followed by systemic developments able to encompass all accountability institutions. The reason for this is that, in spite of incremental advances, there has been no development regarding the procedural ecology of accountability institutions, thus hampering coordinated and cooperative actions between institutions. We analyzed the procedural flow from the Public Sweepstakes Program of the Comptroller General in Brazil as well as the performance of the institutions of the accountability system. We also conducted interviews with the leaders of accountability institutions in order to address the issue of cooperation and strategic coordination of the system of institutions.
\end{abstract}

Keywords: Accountability institutions; control of corruption; institutional change; procedural ecology; accountability process.

\section{Desarrollo institucional y control público: Análisis del Sistema brasileño de rendición de cuentas}

Resumen. Este artículo tiene como objetivo analizar el proceso de desarrollo institucional de las instituciones de rendición de cuentas en Brasil. Los académicos han identificado un proceso de desarrollo incremental de las instituciones de rendición de cuentas horizontal en Brasil, estimulando un proceso importante en la democracia. Nuestro argumento es que el proceso de desarrollo incremental de las instituciones de rendición de cuentas no fue seguido por desarrollos sistémicos capaces de abarcar todas las instituciones de rendición de cuentas. La razón de esto es que, a pesar de los avances incrementales, no ha habido desarrollo en cuanto a la ecología procesal de las instituciones de rendición de cuentas, lo que dificulta las acciones coordinadas y cooperativas entre las instituciones. Analizamos el flujo de procedimientos del Programa de Sorteos Públicos del Controladoría General en Brasil, así como el desempeño de las instituciones del sistema de rendición de cuentas. También realizamos entrevistas con los líderes de las instituciones de rendición de cuentas para abordar el tema de la cooperación y la coordinación estratégica del sistema de instituciones.

Palabras clave: instituciones de rendición de cuentas; control de la corrupción; cambio institucional; ecología procesal; proceso de rendición de cuentas.

* Director de Investigación y Estudios de Posgrado en la Escuela Nacional de Administración Pública (ENAP), Brasil. Profesor del Departamento de Ciencias Políticas de la Universidad Federal de Minas Gerais (UFMG), Brasil. 
Sumario. 1. Introduction. 2. Theories of institutional change: incrementalism and development. 3.The development of accountability institutions in Brazil. 4. Methodology and research focus. 5. The procedural flow of accountability institutions in Brazil. 6. Results: Interactions among institutions in the brazilian accountability system. 6.1. The structure of accountability institutions. 6.2. Institutional cooperation, coordination, and defining strategic priorities. 7. Final remarks. References.

Cómo citar: Filgueiras F., «Institutional development and public control: Analyzing the Brazilian accountability system», en Cuadernos de Gobierno y Administración Pública 5-1, 1-26.

\section{Introduction}

The democratization process in Brazil consolidated a political regime that ensures governability conditions on the one hand, and a process of institutional changes within the political system and public administration, on the other. These institutional changes have paved a new path for the development of a democratic governance for overcoming the particularisms that structure public administration. The 1988 Constitution inaugurated a critical democratization process of the political system and triggered a gradual and incremental process of institutional development within public administration.

Accountability institutions assumed a prominent role in this institutional development process, both in their internal change process as well as in their role in administrative improvements and in establishing democratic governance. From a context in which accountability institutions were absent in Brazil we moved on to a context of established and active institutions in tackling corruption and administrative irregularities.

The main purpose of this article is to discuss this institutional development process by focusing on the performance of control actions for irregularities practiced in Brazilian municipalities. The theoretical discussion revolves around the idea that there has been progress and development in accountability institutions. However, this development process has not engendered systemic developments in the ecology of accountability institutions. The implications of this issue lies in the fact that institutional development must be considered not only within internal organizational changes, but also in a systemic dimension, which considers the ecology of institutions and the procedural flow. This procedural ecology entails an interaction pattern among institutions, explaining the broader systemic results regarding accountability.

The article addressed the performance of Brazil's system of accountability institutions, analyzing the flow of legal and administrative procedures against municipal administrators, covering the sequencing of accountability actions and the coordination and cooperation among institutions. In addition to this performance analysis, interviews with institutional leaders in the accountability system are conducted in order to understand the process of cooperation and coordination within the context of the systemic ecology of accountability institutions.

\section{Theories of institutional change: incrementalism and development}

The issue of institutional change has constituted a crucial element of political analysis. Institutions play a primordial role in society and consequently they influence the 
results of government actions and policies. Institutions represent the rules of the game and they may be formal or informal (Hall; Taylor, 2003). Understanding development processes means understanding that the fundamental analytical problem involved is how to constitute institutional causal mechanisms that can replace the exogenous factors associated to change (Rezende, 2010). In other words, explaining the process of political development means first gaining an understanding of the institutional mechanisms that trigger the change process and alter the rules and the distribution of power. Thus institutional change embraces controversy present in the specialized literature because there is no consensus as to change's causal factors.

Lindblon's classic work states that incremental changes must be understood as being due to the rational nature of the decision making undertaken by political actors. The processes are incremental due to the high institutional costs associated to abrupt ruptures with the accumulated knowledge and with the institutions internal practices. In the same vein, institutional change is incremental because the context of change determines that small additional values will start to be added to the policies so that non incremental changes are, rationally, considered by the decision makers to be irrelevant or without any practical or contextual applicability (Lindblom, 1959). That concept of incremental change does not mean that a policy is transformed small step by small step. Institutional changes may take positive or negative directions whereby strategies can be reviewed in the course of their unfolding, or the context may impose defeats on the policy makers (Weiss; Woodhouse, 1992). The institutional changes occur in contexts of uncertainty, which means that the decision-making processes tend to try to transform policies by incremental amounts avoiding abrupt ruptures and with the aim of effectively achieving incremental changes in practices and results (Lindblom, 1959).

In Douglass North's (1990) view, incremental change processes represent marginal adjustments to complex rules, norms and voluntary obedience structures without which an institutional rupture would occur. Analyzing the institutional change process means understanding the catalyst of change whereby exogenous factors signify those mechanisms that trigger institutional change. Understanding those mechanisms is essential to any analysis of institutional change processes and results.

Pierson (2004) further developed institutional change theories by focusing on the development process. According to that author, gaining an understanding of institutional change would open up four analytical pathways, namely: (1) the theory of critical junctures, focusing on a development process; (2) theories that presuppose the existence of institutional malleability which is explained by the actions of the losing coalitions in the political process (3) the multidimensional aspects and the effects of interaction in the explanation of change, whereby those effects may be intentional or non-intentional; (4) the action of reformers, whereby, in the face of collective action problems, political agents prove themselves capable of undertaking reforms that generate change. Again, according to Pierson (2004), it is important to understand the institutional development process in an incremental way whereby the marginal gains emerge from the exogenous factors unleashed by events external to the institutions themselves.

If on the one hand, the explanation for institutional change processes lies with exogenous factors, on the other, it can also be explained by endogenous factors in which the causal elements of change stem from the behavior of the institutions' internal agents in regard to the institutional forms and contexts (Mahoney; Thelen, 
2010). The agents interpret the context in which they find themselves and act on it, modifying it and re-distributing power. The political conflict stems from the distribution and mobilization of resources and that generates the change process. In other words, it is important to understand the way in which the agents interpret the allocation of political resources and unleash, internally, the process of change directed at their institutions, whether it be an effort to maintain the status quo or one intended to provoke a rupture with it. That ambiguity and conflict regarding resource distribution generate a space for debate about the institutional rules. The greater the degree of ambiguity, the larger the space for contestation on the part of the agents will be, thereby creating a favorable context for endogenous change of the institutions. That does not come about merely from the institutions' formal rules, because they are always open to a political interpretation space. The degree of formalization of the rules in force does not prevent the agents from adhering to them less and, by implication, does not prevent institutional change (Mahoney; Thelen, 2010).

Those authors hold that institutions are not necessarily stable and are always susceptible to change. The agents act on the institutions internally to modify them so, in that case, the way the political context defines their strategies is important. According to Mahoney and Thelen, getting to understand the agents' strategies requires an understanding of the following elements: (1) whether the powers of veto of those involved in the change process are strong or weak; (2) the degree of discretionary power agents enjoy in interpreting rules and procedures and applying them. On the basis of those two variables, discretionary powers and power of veto, it is possible, according to the same authors, to combine the political context with the institutional forms. The relations between the two variables makes it possible to classify the institutional change strategies into four categories, namely (1) - displacement; (2) - layering; (3) - drift; and (4) - conversion (Mahoney \& Thelen, 2010).

Thus the literature acknowledges that understanding institutional change involves understanding the exogenous and endogenous factors in the light of the formal and informal rules that regulate the institutions. In regard to exogenous factors, critical situations and political contexts are what matter in constituting change. As for the endogenous factors, the behaviors and strategies adopted by the agents inside the institutions are of vital importance in enabling an understanding of the institutional change process. In the level of analysis undertaken by Pierson (2004) and by Mahoney and Thelen (2010), understanding the process of institutional change is based on the relationship between agents and structures. On the other hand, such literature does not endeavor to understand institutions' more systemic dynamics.

Outside of the political context and the context of formal rules that delimit the relations between agents and institutional structures, we must also understand the interactions among institutions as being a systemic dynamic in which their relations are interdependent, which means that the change process leads to the formation of institutional coalitions. In other words, apart from analyzing the rules in the light of institutional ambiguity, agents' strategies, critical junctures or political contexts that delineate change, it is also necessary to consider institutions interactions in the context of a complex system of competencies and organizations in which situations of institutional conflict and cooperation make a difference in determining the result of change. The changes may encounter a vetoing situation or one of enforcement according to the performance of other institutions and as a function of the relations of interdependence among the organizations. 
DiMaggio e Powell (1983) identified institutional definition, the process of structuring institutions, as being marked by the following elements: (1) the extent of interactions among organizations; (2) the emergence of domination and organizational coalitions; (3) an increase in the information load that organizations have to deal with; and (4) the development of mutual knowledge among the participants in the set of organizations involved in a joint venture. In other words, the institutional change process goes beyond the boundaries delimited by the organizations themselves and their respective competencies. The change can be interrupted or vetoed altogether, according to the interactions among the institutions and the impact of the institutional rules may be positive or negative, according to that institutional ecology.

Consequently, institutional incrementalism depends on two analytical keys: (1) the interaction between the agents and the institutional structures; and (2) the systemic interaction among institutions. Systemic interaction among institutions, in the sense attributed to it by DiMaggio and Powell (1983), means the formation of an organizational cluster within the sphere of the State that involves mutual knowledge concerning a common public venture undertaken by a set of institutions. The interactions can take the form of an organizational coalition whereby the institutions come together around a common objective, or they may stem from institutional competition that undermines the impact of the development process of each institution in the organizational cluster. Thus the development of the shared knowledge and the control of information become essential to the constitution of organizational clusters that imply either the solidification of the status quo which reduces the impact of changes on an institution or the vetoing of any change at all (Galvin, 2012). Each institution is autonomous in its competences and functions but the result of its actions and of the change process depend on the interaction with other institutions. In that case interaction between political institutions and public administration takes place via fixed formal and informal processes that delimit a procedural ecology.

We take procedural ecology to be the interdependent relations of the institutions system whereby the actions carried out by one institution depend on the actions of other institutions. That interdependency is determined (fixed) by formal and informal rules and procedures that involve a set of institutions in a bid to achieve a certain end. Therefore, it is the process that fixes the ecology in such a way that result depends on the institutions' joint coordinated and cooperative action. An autonomous organization of the institutions intervenes in that process and it determines that the cooperation and coordination of the activities depend, on the one hand, on fixed institutional rules and competencies and on the other, on the establishment of political ties whereby the actors in the institutions understand that the cooperation and coordination of activities are vital for the success of the actions undertaken by the system of institutions. The essential elements for a procedural ecology to function are the knowledge accumulated inside the institutions and the agents' ability to control the information that results from their actions. The chart below displays the explanatory variables associated to institutional change.

We propose the hypothesis that the institutional change process, in addition to the interaction between the agents and the institution, depends on that procedural ecology as its system dynamics whereby the interaction among institutions also matters. The latter interaction is formal because it is embedded in the institutions' procedures, competencies and functions all directed at achieving a certain end. It is also informal, 
Chart 1 . The institutional change process.

\begin{tabular}{|l|l|l|l|}
\cline { 2 - 4 } \multicolumn{1}{c|}{} & \multicolumn{1}{|c|}{$\begin{array}{c}\text { Causal factor of } \\
\text { institutional change }\end{array}$} & $\begin{array}{l}\text { Analytical focus of } \\
\text { the change process }\end{array}$ & $\begin{array}{c}\text { Explanation for institutional } \\
\text { change }\end{array}$ \\
\hline $\begin{array}{l}\text { Exogenous } \\
\text { variables }\end{array}$ & $\begin{array}{l}\text { Critical junctures, } \\
\text { dependence on } \\
\text { trajectory }\end{array}$ & $\begin{array}{l}\text { Political and broader } \\
\text { institutional situation }\end{array}$ & $\begin{array}{l}\text { Shocks external to the institutions } \\
\text { that trigger institutional change }\end{array}$ \\
\hline $\begin{array}{l}\text { Endogenous } \\
\text { variables }\end{array}$ & $\begin{array}{l}\text { Factors associated } \\
\text { to the distribution } \\
\text { of resources among } \\
\text { institutional agents }\end{array}$ & $\begin{array}{l}\text { Organizational } \\
\text { elements internal to } \\
\text { the institutions }\end{array}$ & $\begin{array}{l}\text { Organizational changes that lead } \\
\text { to changes in the distributon of } \\
\text { power among the agents and the } \\
\text { resignification of institutional } \\
\text { objectives and processes }\end{array}$ \\
\hline $\begin{array}{l}\text { Systemic } \\
\text { variables }\end{array}$ & $\begin{array}{l}\text { Interaction among } \\
\text { the institutions of an } \\
\text { organizational cluster }\end{array}$ & Procedural ecology & $\begin{array}{l}\text { Formation of organizational } \\
\text { coalitions, control of information, } \\
\text { institutional cooperation or } \\
\text { conflict processes }\end{array}$ \\
\hline
\end{tabular}

Source: elaborated by the author.

insofar as it depends on determined knowledge shared by the institutions' agents and on the processes of coordination and cooperation associated to the actions. In this case, the informal interactions depend on political conceptions, on the process of interpreting the rules and on the formation of organizational coalitions within the system of institutions.

\section{The development of accountability institutions in Brazil}

We understand accountability to be the principle by which all public officials have the duty to be held publicly accountable for their actions so that society may not only evaluate the resource allocation, but also the actions and results accomplished by policies, programs, and actions proposed and implemented by governments. The concept of accountability refers to the set of procedures and processes circumscribed to modern State bureaucracies, such as internal and external control, through which the public may assess the value added by State policies to the public interest. As such, it is a fundamental principle for the legitimacy of the political system and for the actions of public administration, in addition to being a management tool for ensuring the disclosure of government actions (Philp, 2009; Filgueiras, 2016).

This does not mean that the concept of accountability is a consensus among scholars. According to Mark Bovens, accountability is an evaluative concept and not an analytical concept, used to qualify a state of affairs or the performance of different actors while also referring to a set of practices that make evaluation possible. For Bovens, accountability comprises a kind of social relationship between an actor and a forum through which actors have an obligation to explain and justify their conduct. The forum, on the other hand, may pose questions and judge actors, who answer for the consequences of their actions. Thus, accountability responds to a cycle whereby actors must first inform the forum of their conduct regarding procedures, results, and 
actions. Secondly, the forum may interrogate the actor as to the adequacy of the provided information and the legitimacy and legality of the actor's conduct. Third, the forum may condemn and impose sanctions to the actor. The process of accountability means the actors' duty to account for their actions, the justification and judgment of the actors' conduct, and the possibility to sanction this conduct. Bovens therefore does not rule out sanctions as a crucial element of accountability (Bovens, 2007).

For O'Donnell (1999), accountability is a republican principle, crucial to the functioning of political institutions and of the State bureaucracy in order to ensure transparency and efficiency in the management of public resources and to avert malfunctions. Stemming from a radical premise of separating the public and private dimensions, present in liberal and republican traditions, the basic premise is to ensure publicity in decisions and the implementation and evaluation of government actions for establishing an equalitarian political regime and public administration that is immune to unlawful practices.

An institutional approach suggests that political association with different social contexts generate different potentials for accountability demands (Olsen, 2017). Accountability demands is a element of accountability processes. The process involve rational arguing, deliberation, image-management and blame-games related to what has been done, what could have been done, whether what has been done is acceptable; and also development and change of normative criteria for assessing behavior, explanations and justifications. The likelihood of accountability-demands depends on the institutional, social and behavioral bases of political order, all endogenous to democratic politics. In this sense, accountability process involves two types: (1) accountability routines, that imply institutions and professional actor operating within specialized structures to surveillance and control; (2) - accountability politics, that involves the public debate, deliberation and transformative perspective about the political order (Olsen, 2017). In the sense of this article, the focus is a accountability routines in the accountability process in Brazil.

Institutions of the accountability system must be autonomous and acknowledged by their operators as bearing public authority for supervising, controlling, correcting, and punishing illicit acts in view of preserving the public interest. Moreover, accountability requires a complex institutional network, according to complex competences for control, investigation, and punishment (Mainwaring, 2003). Latin America in general and Brazil in particular, witnessed at the beginning of the democratization process the absence of institutions for horizontal accountability (O'Donnell, 1996, 25). The Brazilian democratization process meant the return of the basic conditions of polyarchy, in view of a transitional process that would come as a reaction to a crisis of the authoritarian regime implemented in 1964. The Constituent Assembly, at the height of the year 1987, faced the dilemma of conducting choices for projecting an institutional planning able to efficiently aggregate and process the growing pressure from an extremely heterogeneous and plural social environment (Abranches, 1988). The return of polyarchy conditions promoted a political opening process essential for establishing democracy (Limongi, 2006). Parallel to the return of elections, an incremental development process of state institutions began, including horizontal accountability institutions. Political competition, political opposition, and clearer institutional rules have encouraged the development of horizontal accountability institutions (Melo, Pereira and Figueiredo, 2009). 
Political change in Brazil has led to an incremental development process in institutions. However, in face of a political regime that ensures governability conditions, there has been a cost in democratic governance conditions within the public sector, leading to an antagonism between the use of political authority on the one hand, and the use of public authority in administration, on the other. Moreover, these incremental changes in institutions within Brazil's accountability system meant for a greater capacity to expose and publicize several corruption scandals, enabling junctures leading to rule changes, and strengthening the role of these institutions in society. That is, insofar that corruption in the public sector was being revealed, control and accountability mechanisms were strengthened (Taylor, Praça, 2014). From this process we verify a growing spiral of institutional incrementalism, which aggregates new functions to accountability institutions (Filgueiras, 2013).

The 1988 Constitution established fixed competences to a set of institutions within a complex framework for controlling and supervising government powers. This institutional competency framework refers to a theoretical understanding where all republican powers must exercise the internal control of activities, and the Legislative Branch must exercise external control through the Federal Court of Accounts. Additionally, the Constitution delegated powers to the Public Prosecutor's Office for controlling the public administration in addition to judicial and extrajudicial solutions ${ }^{1}$.

Through the 1988 Federal Constitution, the Federal Court of Accounts becomes responsible for the external control of public administration through oversight practices and for informing the National Congress on the correct exercise of powers delegated to public agents. The Federal Court of Accounts was created in 1891, being responsible for verifying the legality of the Executive Power's accounts. Its name refers to it being an administrative court, whose primary aspect would the prescribed legality in the application of accounts. Since its creation in 1891, the court has gone through incremental changes. Over time, the Federal Court of Accounts has been expanding its scope, especially in 1967, when it was provided with the authority to conduct administrative audits. The Federal Court of Accounts left behind its strictly legalistic competences to assume competences pertaining to performance audits and public administration control (Speck, 2000). This led to a critical juncture for the Court, since it entailed changes in entrenched practices within its administration as well as the expansion of its functions. One other critical juncture, which represented a major change in the Federal Court of Accounts, was the Fiscal Responsibility Act, through which administrative and auditing practices were added and regulated, requiring the institution to modernize its internal practices and to invest in technology (Loureiro, Teixeira, Cacique, 2009).

In the case of the Public Prosecutor's Office, the establishing of its competences through the 1988 Constitution also represented a critical juncture. The Federal

\footnotetext{
The extrajudicial solution is a non-judicialized way of resolving conflicts. In Brazil, the Public Prosecutor's Office is the agency responsible for suggesting legal solutions for conflict resolution. The Public Prosecutor's Office is also responsible for suggesting recommendations and terms of conduct adjustment for the exercise of accountability and public administration control. A recommendation is nothing more than the instrument used by the Public Prosecutor's Office to alert public officials about the need to resolve a given irregular situation or a situation that could lead to irregularity. The conduct adjustment agreement (TAC) is a legal instrument used to obtain from the tortfeasor, responsible for causing damage to diffuse and collective interests, an enforceable obligation of do's and don'ts through which the tortfeasor assumes the duty to suit their conduct to legal requirements, under penalty of sanctions laid down in the term itself.
} 
Constitution assured the functional and administrative autonomy of the Public Prosecutor's Office, making it further immune to political interests and more empowered to act in the public stage. Through functional autonomy, the Public Prosecutor's Office is responsible for exercising a justice function within the State, befalling upon it the defense of collective and diffuse social interests. It also becomes responsible for the defense of the democratic regime through the protection of public and social heritage. The Public Prosecutor's Office is also responsible for a judicial function within the State, not limited to the defense of the State, monitoring, control, and punishment of administrative irregularities. Its competences are broader. For the purposes of this research, however, the Public Prosecutor's Office is responsible for the crucial function of horizontal accountability due to its competences for supervision and judicial action against public officials and elected politicians (Arantes, 2011a).

The same happens with Federal Police. The Federal Police is the Union's judicial police, responsible for investigating criminal offenses against public and social order, against assets, services, and interests of the Union or of its autarchic entities and public companies, as well as other offenses with interstate or international consequences that require uniform repression. The Federal Police was created in 1944 near the end of the Estado Novo Regime as a Federal Department for Public Safety, but its functions were confined to the Federal District. In 1945, it gained national powers. Only with the 1988 Constitution were its competences fixed as the judicial police of the Union, recognized as a permanent body and with a career structure. The permanent nature of the Federal Police means that even when subordinated to the Executive Branch, the Federal Police cannot be dissolved by the government. In the second case, the structuring of the Federal Police in a career means rules for access to positions, a police hierarchy, and rules for career ascension and organizational subdivisions with defined competences. From this, the Federal Police board members expanded over time, beyond the budgetary growth of the institution. The internal socialization of agents and police chiefs within the institution holds a strong reinforcement component of repressive actions against organized crime and corruption, alongside a strengthening of democracy (Arantes, 2011b).

Lastly, the creation of the Comptroller General of the Union in 2003 establishes a long incrementalism process for the internal control of Brazil's public administration. Prior to the Comptroller General of the Union, the internal control system was decentralized across the several public management organs and coordinated by the Federal Internal Control Secretariat, under the Ministry of Finance (Olivieri, 2010). Law 10683/2003 founded the Comptroller General of the Union (CGU), which, with functional autonomy it took over and centralized every internal control activity of the Federal Government as well as initiatives for preventing and fighting corruption. The CGU represented an important innovation process in Brazil by not only centralizing internal control activities and institutionalizing its practice within public administration, but also for disseminating management and transparency practices. For Brazil, the CGU represents a process of functional conversion dictated by critical junctures of corruption scandals in the transition between the Fernando Henrique Cardoso administration to the Lula administration (Filgueiras e Araújo, 2014). The institutionalization of internal control allowed greater enforcement capacity, control, and monitoring of public policies in order to advance the accountability process (Balbe, 2013). 
The 1988 Constitution and the return of democracy in Brazil represented an essential critical juncture, which triggered these incremental changes in accountability institutions. Firstly, by setting a complex and large chain of competences, rules, and processes at the institutional pinnacle. Secondly, because the 1988 Constitution led to changes in the organizational structure and practices within these institutions. Therefore, incremental changes were established from a context of empty horizontal accountability institutions in Brazil, which meant for the development of new public management practices and the gradual empowerment of accountability institutions. This resulted in the construction and development of a system of accountability institutions with unique and superimposed competences for prevention, investigation, and punishment of illicit acts within the political system and public administration. Corruption scandals served as catalysts in the change process, maintaining the incrementalist development of accountability institutions (Taylor, Praça, 2014).

The presence of these scandals in Brazil has placed corruption in the eye of the public opinion. There is something in common to all of these scandals. First of all, the massive media coverage publicizing corruption schemes and misuse of public funds. In Brazil, there is a pulsating and autonomous media to cover corruption cases, which play the role of watchdogs toward the political system (Porto, 2011). Secondly, all these corruption scandals are within a context of a social critique of politics, corroborating a widespread view that the Brazilian State is the natural space of vices. Third, all of these corruption scandals gave rise to ad hoc initiatives of public control, catalyzing an institutional change process in accountability institutions.

Institutional changes came in reaction to the critical junctures brought forth by corruption scandals. The reaction of the presidents was to promote anti-corruption initiatives and policies in the following areas: $(1)$ - the dissemination of these policies due to the fact that Brazil had become a signatory to international conventions against corruption; (2) - the superposition of new organizational formats in public administration, as in the case of the creation of the Comptroller General of the Union and the greater autonomy of the Federal Police, leading to the coexistence of new and old institutional formats; (3) - the functional conversion of institutions, such as the Federal Court of Accounts, which were given further prerogatives and autonomy. This whole process of institutional change is grounded on a development process driving a path dependence situation, in which the route assumed by change involves gradual institutional strengthening (Pierson, 2004).

However, these changes did not result in broader systemic developments concerning the interaction and complementarity processes that each institution holds with other institutions, in view of the procedural ecology of control actions and accountability. Procedural ecology is an interdependent relationship within the system of institutions, where actions taken by an institution depends on the actions of other institutions. This interdependence happens within rules and procedures involving a set of institutions to carry out a goal. The process, therefore, places this ecology in such a way that the result depends on the joint, coordinated, and cooperative action of institutions. The system of accountability institutions has this procedural ecology set on certain rules and procedures involving a set of institutions to conduct the purpose of control actions, in view of the activity sequencing defined in the process.

This procedural ecology involves what DiMaggio and Powell (1983) called the institutional definition, which marks the institutional structuring process through the 
following elements: (1) - the extent of interactions between organizations; (2) - the emergence of domination and organizational coalitions; (3) - an increase in the informational load with which organizations must deal; (4) - the development of a mutual understanding among participants within the set of organizations with a common undertaking. In the system of accountability institutions in Brazil, however, the interaction process is marked by institutional interdependence, since institutional rules are superimposed and complementary. An increased interaction among institutions of the accountability system does not result in cooperative or coordinated joint actions since organizations rationally struggle for recognition from the public opinion. Procedural ecology, marked by the interdependent and complementary relationship between institutions, implies in a relationship between processes and rules, on the one hand, and an institutional structure of cooperation and coordination by the actors, on the other.

Institutional change in Brazil was not accompanied by an ecological change in the system of accountability institutions, in which interactions among these institutions is unable to produce coordinated and cooperative actions, thus failing to ensure a rational sequencing of activities destined to the improvement of accountability. Interactions between institutions of the accountability system in Brazil occurs procedurally in under-coordinated competences and processes, fueled by a political action guided by the critical junctures of corruption scandals. ${ }^{2}$

\section{Methodology and research focus}

As previously stated, the main purpose of this article is to apprehend the performance of accountability institutions in Brazil and the process of interaction between these institutions. To that end, we must therefore comprehend a control action implying and encompassing a set of institutions, in order to allow for an analysis of the procedural ecology of control actions in the system of accountability institutions. To evaluate this performance and comprehend the interaction between institutions, our chosen starting point is the control actions of the Public Sweepstakes Program of the Comptroller General of the Union (CGU).

The Public Sweepstakes Program was established in 2003 with the objective of promoting in loco auditing of federal public funds transferred to Brazilian municipalities. The Program is based on a random drawing of 60 municipalities per year, to which auditors are sent for an internal control by the CGU, which investigates the rendering of accounts, the financial allocation of resources, and public goods and services produced with these federal funds. The audit does limit itself to an assessment of accounts, but also verifies the allocation of funds in order to assess whether the allocation of federal funds has reverted itself in goods and public services in the municipalities. The draws are randomized and based on the regional distribution of municipalities among states.

It is important to highlight that we do not address in this text the issue of societal accountability. In the case of Brazil, there is an instance of public control that occurs through the participation of society through public policy management councils. These councils extend to the municipal, state and federal levels and can exercise, through the participation of citizens, forms of control and inspection of public resources. Public policy councils are participatory bodies, representing civil society and governments in the decision-making process on the application of resources and monitoring of accountability by governments. In this regard, see Avritzer (2012). 
Our choice for the CGU Public Sweepstakes Program as our starting point has three reasons: (1) - the Public Sweepstakes Program allows us to extensively verify the actions of institutions of the accountability system insofar that it encompasses public policy managers and other institutions related to both the judicial prosecution of irregularities as well as non-judicial public control measures; (2) - the Public Sweepstakes Program allows us to verify a more generic set of irregularities, embezzlement, and signs of corruption in the public sector, as it deals with resource transfers to federal entities and allows us to verify the dissemination of management flaws within the Brazilian public administration; (3) - the focus of the CGU Public Sweepstakes Program as a starting point permits us to verify the public administration control actions without interference from exogenous factors, such as the prospect of a political scandal. Since we are dealing with widespread irregularities in public administration, the Sweepstakes Program, through its reports, allows for a wider and more detailed verification of the quality of Brazil's public administration.

Having made these considerations, we take the CGU Public Sweepstakes Program as the starting point for our research. We have assembled a database with all the irregularities found in the audit reports from a sample of 322 municipalities, from a total 1800 randomly selected municipalities, between 2003 and 2010. The reason we chose this time interval is because of the problem posed in the research. Since the objective is to verify the actions of the set of institutions in the accountability system based on the information compiled from the audit reports, this time period was chosen based on the deadlines for the other institutions to undertake investigative and punitive actions. Since the objective is to verify the performance of the system of accountability institutions and its internal interaction, this period is necessary so that each one may undertake the necessary formal actions for investigating and punishing irregularities. The sample was comprised of 322 municipalities, and stratified by region, state, and draw number, in order to meet a more balanced distribution among municipalities already audited by the Public Sweepstakes Program. The randomly selected municipalities have up to 500 thousand inhabitants, excluding state capitals. From this data for the sample of municipalities, we traced the processes in the other institutions originating in the Public Sweepstakes Program.

With this procedure, we established a database allowing us to verify the flow of all processes involving administrative, judicial, and extrajudicial procedures, according to the competences of each institution. The data allows us to verify the performance of the system of institutions regarding public control processes and the interaction between them, stemming from the premise that public control actions involve a complex procedural ecology, with specific competences, ranging from investigative actions to punishing irregularities, embezzlement practices, and corruption. Our analytical unit consists of each of the irregularities found in the Public Sweepstakes Program reports within the sample.

To verify the interaction that these institutions of the accountability system have among themselves, the survey also performed a qualitative approach. We conducted interviews with leaders of the Comptroller General of the Union, the Federal Public Prosecutor's Office, the Federal Court of Accounts, the Federal Police, and the Federal Court, which deal directly with public administration control actions and actions against corruption. The purpose of these interviews is to establish an explanation for the performance issues raised in the quantitative approach, stemming from the hypothesis that such poor performance is due to problems in the procedural ecology of 
the institutions within the Brazilian accountability system. The interviews with leaders of these institutions allow us to assemble the puzzle of power relations and political disputes occurring within Brazil's accountability system.

Sixty-three interviews were done in total. Interviews were conducted with 18 leaders of the Comptroller General, 15 leaders of the Federal Court of Accounts, and 14 leaders of the Federal Public Prosecutor's Office between June 2 and June 6, 2014. The interviews with 10 Federal Police superintendents and commissioners and 6 Federal Court judges were conducted between 25 and 27 February, 2015.

From the qualitative data collected through interviews, we conducted an analysis of the interaction between accountability institutions. The motivation behind this analysis is to understand how these institutions interact and to find an explanation for the performance results obtained from the control actions motivated by the Public Sweepstakes Program.

\section{The procedural flow of accountability institutions in Brazil}

An analysis of the audit reports of the CGU Public Sweepstakes Program allows us to understand the quality of municipal governments in Brazil and the actions of the institutions in the accountability system (Rothstein, 2011; La Porta, et al, 1999). From a substantial point of view, it allows us to analyze the capacity by which public policies are implemented at the municipal level in Brazil to improve the quality of life of citizens. Since we are dealing here with the allocation of federal resources in the municipalities, with the prerogative of improving development conditions, the analysis of the reports provides an accurate picture of the quality of municipal governments and the implementation of public policies. The assumption is that municipalities are Union partners in the implementation of public policies, in view of a substantial aspect of promoting economic, political, and social development, associated with strict procedures under Brazilian law for the decentralization of public resources within the Federation.

The municipalities comprising the sample have specific characteristics. In general, they are small municipalities, with a moderate human development index and heavily dependent on the transfer of resources from the Union. According to the data in Table 1 below, on average, $44.10 \%$ of the budget of the municipalities in the sample comes from funds transferred by the Union. The mean population in the sample is 26,720.8 inhabitants, with an average illiteracy rate of $23.0 \%$, and an average urbanization rate of $57.44 \%$. These are generally poor municipalities, with an average poverty rate of $45.48 \%$ and an average GDP of R $\$ 198807.26$. On average, $62 \%$ of the active employees in the municipality's direct administration are statutory, with stability. With these characteristics, the municipalities are dependent upon the Union for the development of public policies and lack sufficient infrastructure for administrative autonomy and government quality. The dependency ratio is high, making these municipalities liable to minor and major corruption practices.

In the audit reports of the Public Sweepstakes Program, for the sample of 322 municipalities used in this research, we found irregularities in 19153 municipalities. These irregularities range from small procedural flaws to serious evidence of corruption practiced at the municipal level. We proceeded to classify the 19153 of irregularities found in the audit reports of the CGU Public Sweepstakes Program in order 
Table 1. Descriptive data of the sample's municipalities

\begin{tabular}{|l|c|c|c|c|c|c|}
\hline \multicolumn{1}{|c|}{ Index } & N & Minimum & Maximum & Average & $\begin{array}{c}\text { Standard } \\
\text { Deviation }\end{array}$ & Variance \\
\hline Population size & 322 & 795 & 363392 & 26720,8 & 46515,9 & 2,164 \\
\hline MHDI & 322 & 0,272 & 0,813 & 0,546 & 0,114 & 0,013 \\
\hline $\begin{array}{l}\text { Gross domestic } \\
\text { product in current } \\
\text { prices (R } \$\end{array}$ & 322 & 6853,00 & 4771863,00 & 198807,26 & 460293,47 & 2,119 \\
\hline Illiteracy rate (\%) & 322 & 1,90 & 65,5 & 23,0 & 12,25 & 150,15 \\
\hline Urbanization rate & 322 & 4,18 & 100,0 & 57,44 & 21,80 & 475,30 \\
\hline Poverty incidence & 322 & 11,05 & 84,00 & 45,48 & 14,82 & 219,90 \\
\hline $\begin{array}{l}\text { Number of active } \\
\text { employees in direct } \\
\text { administration }\end{array}$ & 322 & 19 & 6568 & 850,87 & 985,76 & 971724,91 \\
\hline $\begin{array}{l}\text { Amount of active } \\
\text { statutory employees in } \\
\text { direct administration }\end{array}$ & 322 & 0 & 4161 & 529,07 & 699,96 & 489495,56 \\
\hline $\begin{array}{l}\text { Resources transferred } \\
\text { from the Union to the } \\
\text { municipality in the } \\
\text { draw year (R\$) }\end{array}$ & 322 & 11983,45 & 181513291,40 & 12320358,15 & 19471356,33 & $3,791 \mathrm{E} 14$ \\
\hline $\begin{array}{l}\text { Municipal revenue in } \\
\text { the draw year (R\$) }\end{array}$ & 322 & 53610,72 & 338287868,70 & 27933871,42 & 52674274,76 & $2,775 \mathrm{E} 15$ \\
\hline $\begin{array}{l}\text { Ratio between } \\
\text { income and resources } \\
\text { transferred from the } \\
\begin{array}{l}\text { Union in the draw } \\
\text { year }\end{array}\end{array}$ & 322 & $22,35 \%$ & $53,65 \%$ & $44,10 \%$ & & \\
\hline
\end{tabular}

Sources: Brazilian Institute of Geography and Statistics, Basic Municipal Information Survey; PNUD - Municipal Human Development Index - Brazil.

to identify the sector or nature of the found irregularity. Table 2 below shows the classification of such irregularities.

From a total of 19153 irregularities found, the majority are in the financial sector and in the municipalities' available infrastructure. The bulk of these irregularities concerns procedural flaws in view of non-compliance with the rules of government programs as well as with the general rules of resource decentralization. Irregularities on public policy councils relate to the certain obligations of municipalities regarding the establishment of participation councils for monitoring resource allocation. In the audit reports, the meeting minutes are checked as well as the rules for its creation, and the regularity of meetings. Irregularities in public procurements concern problems in Law 8.666, which sets public procurement pro- 
Table 2. Classification of administrative irregularities

\begin{tabular}{|l|c|c|c|c|}
\hline Type of administrative irregularity & Frequency & Percentage & $\begin{array}{c}\text { Valid } \\
\text { percentage }\end{array}$ & $\begin{array}{c}\text { Cumulative } \\
\text { percentage }\end{array}$ \\
\hline Irregularities in public policy councils & 1162 & 6,1 & 6,1 & 6,1 \\
\hline Irregularities in public procurements & 3181 & 16,6 & 16,7 & 22,8 \\
\hline $\begin{array}{l}\text { Irregularities concerning transparency } \\
\text { problems }\end{array}$ & 1242 & 6,5 & 6,5 & 29,3 \\
\hline Irregularities in public construction & 1070 & 5,6 & 5,6 & 34,9 \\
\hline Irregularities in infrastructure & 3600 & 18,8 & 18,9 & 53,7 \\
\hline Financial irregularities & 4587 & 23,9 & 24,0 & 77,7 \\
\hline Administrative irregularities & 925 & 4,8 & 4,8 & 82,6 \\
\hline Faults in other organs & 407 & 2,1 & 2,1 & 84,7 \\
\hline $\begin{array}{l}\text { Irregularities concerning the target } \\
\text { audience }\end{array}$ & 1541 & 8,0 & 8,1 & 92,8 \\
\hline Irregularities concerning registration & 1375 & 7,2 & 7,2 & 100,0 \\
\hline Not applicable* & 63 & 0,3 & - & - \\
\hline Total & 19153 & 100,0 & 100,0 & - \\
\hline
\end{tabular}

* Not applicable relates to irregularities not regularly described in the reports, preventing their classification.

Source: Public Sweepstakes Program - Comptroller General of the Union, 2003-2010.

cedures and publicity rules for public tenders, as well as rules for purchasing and hiring within the public sector. Irregularities in transparency issues concern publicity problems in public acts conducted by the sampled municipalities. Problems in construction relate to unfinished constructions, performed with inappropriate material, unperformed constructions, and works not in compliance with the requirements for the construction of public applications. Infrastructure problems concern the physical infrastructure and personnel available in municipalities for the implementation of programs and partnerships. Administrative irregularities refer to the municipalities' organizational issues, such as the existence of master plans and the organization in programs and partnerships. Faults in other organs concerns irregularities in which the execution of programs and partnerships does not depend solely on the audited municipality, but on other organs, such as the State or the Union itself. Irregularities referring to the target audience concern the correct application and destination of public funds to the target audience for programs and partnerships established with municipalities. Resources from the Bolsa Familia Program are one example, which should be forwarded directly to beneficiaries and municipalities should not receive shared remuneration over decentralized resources. Lastly, we have irregularities concerning registration, which refer to problems found in public records and information management, where privileges or misapplication of public funds are concerned. 
Brazil's public administration control is conducted through administrative and criminal procedures, which not only focus on correcting the use of public resources, but also on correcting the public administration principles in Article 37 of the Constitution, especially regarding legality, impartiality, efficiency, economic efficiency, and publicity. The effective exercise of probity control in relation to these principles, therefore, calls for the complex workings of a procedural ecology, ranging from accountability to judicial prosecution processes. Thus, a system of accountability institutions demands that these institutions work in the context of a complex web of procedures, obeying the following principles, as defined by Doig and McIvor (2003):

- Time control and strategic intervention;

- Establishing priorities for action;

- Coordination;

- Cooperation;

- Sequencing.

In spite of the efforts in establishing strategic actions and the efforts to coordinate the activities of the institution, the results revealed by an analysis of the Public Sweepstakes Program are well below expectations. The interaction between institutions conducting auditing and resource decentralization control for Brazilian municipalities and the criminal and administrative prosecution process, as well as the extrajudicial solutions, are below expectations. Figure 1 summarizes the results of the ecological flow of processes among institutions of the accountability system, revealing the gradual evanescence of control as the procedural flow advances forward.

Figure 1 shows the percentage of irregularities found in the Public Sweepstakes Program communicated to the other institutions within the accountability system. From a set of $100 \%$ of irregularities presented in the Public Sweepstakes Program audit reports, 49.6\% were analyzed by the Federal Public Prosecutor's Office, $32.35 \%$ of these irregularities were finalized in the Federal Public Prosecutor's Office, and $10.5 \%$ of them were archived. Only $0.93 \%$ of these irregularities were inferred in Federal Police investigations and only $1.28 \%$ of these irregularities were analyzed in the Federal Court of Accounts. Under the Federal Court, only $4.25 \%$ of these irregularities suffered lawsuits, with only $1.64 \%$ of all irregularities being sentenced in the first instance of the Federal Court. From this set of irregularities raised in the Public Sweepstakes Program (19153 irregularities), only $1.27 \%$ of them resulted in convictions of public administrator responsible for allocating federal funds.

By considering the irregularities found in the sample, we may realize that a fair portion of them were not even analyzed or considered by other institutions. In other words, many of the control actions are lost or disregarded in the procedural flow. We have raised the hypothesis that poor performance happens because, in spite of the efforts to coordinate the activities of the institutions of the accountability system and the establishment of goals, inter-institutional cooperation is low for public administration control. When observing figure 1, we see a very low performance of joint administrative and criminal actions, being a result of the interdependence of processes in the ecological matrix of accountability institutions. By observing 
Figure 1. Quantitative performance of administrative and judicial procedures informed by the public sweepstakes program analytical unit: Irregularities.

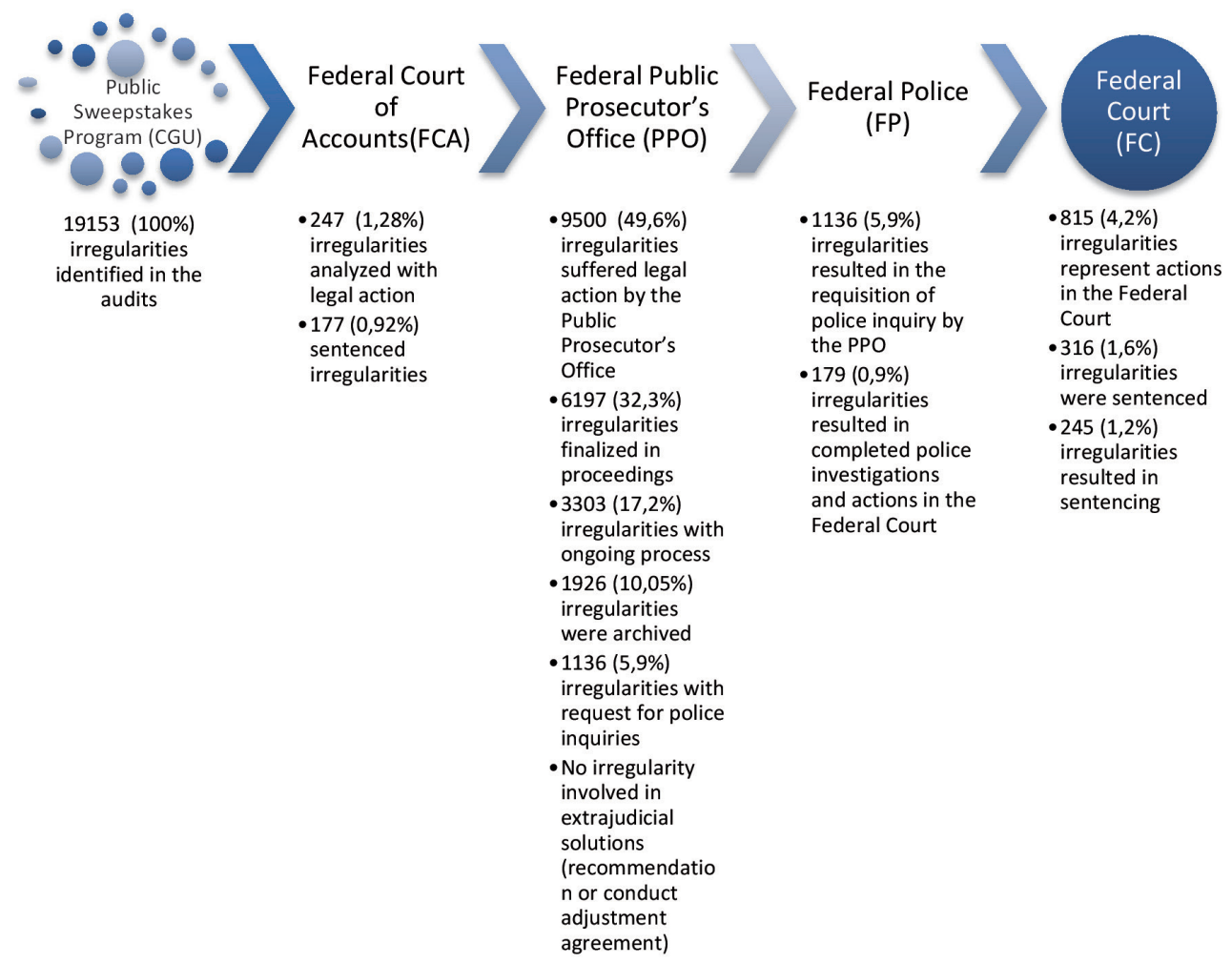

the actions of the institutions in the Brazilian accountability system, we notice that institutions filter the referrals from the Comptroller General, leading to a feeble process in the liability and punishment of irregularities within the municipalities' administration.

Underperformance also occurs if we change the analytical unit of the municipalities. In the context of the sample, only 175 municipalities had their report analysis finalized by the Federal Public Prosecutor's Office. Only 13 municipalities were the subject of a police inquiry in the Federal Police. 32 municipalities had their administrators convicted in the Federal Court of Accounts of the Union and 20 administrators were convicted in the Federal Court, as shown in Figure 2. We should underline that no recommendation or conduct adjustment agreement was found for the sampled municipalities.

Poor performance originates from the low cooperation between institutions of the accountability system. However, this happens not when establishing objectives or in the decision-making process concerning the priorities of institutional action, but in the day-to-day control on public administration and the ecological flow surrounding administrative, judicial, and extrajudicial procedures. The next section analyzes the interaction between institutions in Brazil's accountability system. 
Graph 2. Quantitative performance of administrative and judicial procedures informed by the Public Sweepstakes Program Analytical unit: Number of municipalities.

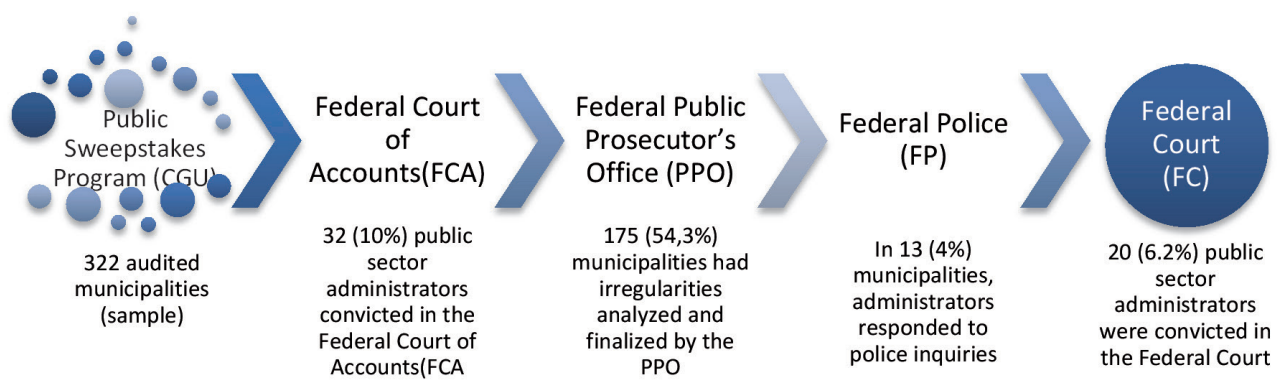

\section{Results: Interactions among institutions in the brazilian accountability system}

The questions raised in the previous sections allows us to establish a diagnosis based on the flow of processes in irregularity control actions regarding the public administration of Brazilian municipalities. From the above charts and graphs, we may conclude that a number of control measures are lost in the procedural flow, which requires specific actions from each of the institutions involved as well as coordinated actions from the institutions of the accountability system. In other words, hypothetically, we may affirm that from the information gathered on municipal public administration in Brazil, within our sample, the result is ineffective regarding the accountability of public officials.

The analytical procedure of interviews with leaders of accountability institutions sought to understand two sets of questions: (1) - an understanding of the institutionalization of the accountability system in Brazil; (2) - the cooperation, coordination, and definition of strategic priorities within the system of accountability institutions.

\subsection{The structure of accountability institutions}

Notwithstanding the constitutional competences of these institutions, the daily work performed within them - by employees assigned to complex tasks pertaining to internal control, external control, investigation, and judicial and extrajudicial solutions - allows us to identify an ethos that is unique to these institutions. Through available research tools, we were able to find that institutions of the Brazilian accountability system have their own conception of the management mechanisms, articulating an almost existential conception for defining their role within the Brazilian state in general and in the context of public administration in particular.

This ethos shapes these institutions as an insulated place within the Brazilian State, consisting of very skilled public employees, with solid technical knowledge and focused on functions determined in regulatory arrangements (Nunes, 1997). This scenario can be found in all analyzed institutions, in which their insulation toward clientelism and corporatism mechanisms establishes a kind of immunity to more immediate political interests. In general, actors in these institutions are highly 
qualified individuals, appointed through public tender for performing tasks within the bureaucracy. However, one issue calls our attention in several discourses from the respondents: their distance from party politics, criticisms toward the Legislative Power, and criticism toward politics.

This critique toward politics and representation resonated constantly across all interviews. Therefore, through the interviews were able to detect that the configuration of the professional ethos of these institutions seeks to oppose any form of intervention from political interests and representation. Institutional leaders and professionals see themselves as watchmen, opposed to political representation, and consider their main role to be the establishment of some type of control over public management, both in regard to formal irregularities and corruption within the Brazilian State. The leaders of these institutions indicate a position of counter-democracy. According to Rosanvallon's argument, counter-democracy is the emergence of a surveillance power, the multiplication of powers, and a growing judicialization of politics in view of a growing distrust in democratic societies (Rosanvallon, 2006).

The central role played by these institutions within the public administration scenario in Brazil is to tackle any form of irregularity in the use of public resources and in the control of public policies. It is important to stress that we did not find among the interviewed leaders a concern with the results of State actions within society, but rather, above all, with the formal and legal control in the application and implementation of public policies. Such a surveillance role from these institutions, as mentioned in different interviews, pertains to the control of public administration in opposition to political actions in view of heavily institutionalized public action mechanisms. This institutionalization process of institutions of the accountability system creates deep conflicts with the political system, making it so the process of institutional change often becomes a process of coercive isomorphism (DiMaggio and Powel, 1983, 150).

One must remember that the institutionalization of these institutions of the accountability system respects their procedural and formal conception, in which competences are fixed and clear to their leaders, ensuring, as indicated by the interviews, that there exists a strong autonomy for action by these institutions within the State. However, one important finding of this research regarding competences calls our attention. Institutions have strongly institutionalized competences and act exclusively within them. In a way, the institutionalization of these competences promotes a technical and defined work within each institution, in a way that the process becomes determinant to the success of control and surveillance actions within the State. Therefore, strong institutionalization does not establish a gray area in the agency of these accountability institutions, and we find a well-defined process in place. The problem we detected from the interviews is that there is no motivation for joint and coordinated actions, and therefore, in addition to the insulation and criticisms toward institutions for political representation, insulation also exists toward all institutions of the accountability system. By besieging themselves solely around their competences, this leads to a mechanism providing little incentives for cooperative and coordinated actions, and thus the institutional conflict occurs both in the external dimension of the accountability system, where it clashes with the political system, as well as the internal dimension, where institutions are in conflict among themselves.

This becomes blatant when respondents were asked about the trade-off between corruption and development. Corruption involves high transaction costs in the public 
service. The economic costs of corruption represent consequences to the reduction of incentives for productive investment, since corruption is seen as yet another fee that needs to be paid off, thus reducing the profitability of projects (Shleifer, Vishny, 1993). Lastly, corruption reduces the effectiveness of resources distributed through the public sector, thus also representing a high cost of social injustice (Rose-Ackerman, 1999).

On the other hand, tackling corruption entails high expenditures with control institutions and bureaucracy, leading to an expansion of bureaucratic processes, licenses, permits, and formal procedures for conducting public services and productive activities. Just as corruption involves high transaction costs, and hampers the business environment, the activities of the bureaucracy against corruption also affect development due to the high costs of unproductive activities (Leff, 1964). Furthermore, the expansion of the bureaucratic control of corruption generates negative effects within the State, establishing bureaucracies that are refractory to any innovation or business, fearing they will fall into the mass grave of corruption. Therefore, control of corruption would also represent a high cost for development, and quite often an insurmountable barrier (Anechiarico, Jacobs, 1996).

Interviewees positioned themselves wholly against the trade-off between corruption and development, and considered it a fallacy. This position was quite clear among all respondents. While respondents recognize that an increase in the inherent bureaucracy with increased public control of corruption leads to development costs, they refuted this trade-off, presenting the fight against corruption as a constitutive element of the institutionalization process of institutions of the accountability system. On the other hand, the political system perceives the role of these institutions as inappropriate and heavily marked by political persecution.

Within this context, operators from different institutions of the accountability system, with clear and institutionalized competences, play a surveillance role in public administration, asserting their role as counter-majoritarian institutions, i.e., without political or party ties, strongly autonomous in relation to social pressures, and with a high degree of discretionary actions within Brazilian public administration. In the context of these institutions, their leaders incorporate control actions toward the formal means of public administration, without further concerns as to the achieved social benefits and results. According to its leaders, these institutions should be able to anticipate political institutions and establish increased surveillance mechanisms within democracies against representation.

\subsection{Institutional cooperation, coordination, and defining strategic priorities}

Institutional cooperation and coordination must be understood as a crucial element for public administration control and for tackling corruption. Firstly, we should not consider each institution in isolation or self-sufficiently within a complex institutional context. There exists subsidiary relations and complementarities between institutions, where actions from one institution are complemented by actions from others, bearing in mind that procedural ecology must be solid and consistent. Therefore, it makes more sense to address the issue of coordination and cooperation among institutions as the formulation and performance of the system of accountability institutions. Institutional cooperation and coordination are essential for the proper functioning of the institutional system. This systemic and procedur- 
al consistency, when broken, explains the poor performance of the system of accountability institutions.

What particularly called our attention in the interviewees' accounts on this subject is that tackling management irregularities promotes an institutional dispute. Assuming that corruption scandals generate public attention toward public administration and politics, fighting corruption and activating accountability institutions promotes the formation of a critical juncture. Within this juncture, the work ends up being focused on seeking results for the institution assuming the leading role. To be a protagonist in the fight against corruption in the public sphere generates interest from the public opinion. As mentioned by one of the interviewees:

Most respondents were emphatic in stating that there are difficulties in institutional cooperation. Political dispute between institutions means that there is little cooperation, especially when it comes to tasks that require coordination and promptness. The low effectiveness in institutional cooperation within this system of institutions does not occur, therefore, through a normative vacuum. Respondents were categorical in stating that cooperation agreements exist and they increase interaction between institutions. However, even though the performance of these institutions must be systemic, the political dispute context ultimately compromises joint and coordinated actions, placing the issue of institutional change mostly centered in the procedural ecology than in the isomorphism process of the institutions.

The second factor hampering institutional cooperation stressed by respondents pertains to the lack of a common procedure or evaluation and auditing standards among institutions. For example, respondents cited the lack of measurement and evaluation standards for construction works. Since institutions adopt different standards for their engineering staff, there lacks a common investigation, which results in huge amounts of repeated works, process delays, and evaluative differences.

Thirdly and resulting from the second factor, a procedural inconsistency exists among institutions, especially in disagreements as to the procedures and norms for auditing procedures and civil and criminal prosecutions. This inconsistency occurs due to differing interpretations concerning procedures and public service standards, resulting in inconsistency regarding the necessary normative terms for the workings of accountability institutions. Many respondents reported a dispute among institutions when it comes to interpreting the law, leading to delays and reworks in processes.

As noted by the interviewees, cooperative efforts do exist. However, the political dispute among institutions ultimately hampers a more systemic composition of the institutions. The presence of the Control Network, according to the interviewees, was an important institutional progress ${ }^{3}$. However, dispute still exists among institutions, even if cooperation agreements have been signed. Competence complementarity requires that institutions uphold dialogue and information exchange. However, as some respondents said, information exchange is still a feeble element as there is no coordinated information sharing among accountability institutions. The result is that this institutional change process in accountability institutions produced specific

The Control Network is an inter-organizational decision-making center for improving the effectiveness of State control over public administration. From 2009, the Public Administration Control Network began to be implemented through workshops in Brasilia and the employment of networks within the states. The main objective of the Control Network is to develop actions for public management monitoring, diagnosing and tackling corruption, encouragement and strengthening of social control, the sharing of information and documents, exchange of experience, and staff training. 
incremental changes, without altering procedural ecology due to an explicit conflict among institutions of the accountability system.

Respondents were unanimous in stating the need for information sharing and the creation of a joint intelligence system as a key element in the development of the system of accountability institutions. This element, according to some respondents, would provide greater institutional cooperation, but would demand a reform addressing the issue of secrecy, especially banking and tax secrecy, which could provide greater power to this intelligence system. According to the interviewees, the issue of shared information has become a key element for cooperation within this institutional control system.

However, we found in the interviews that on top of cooperation issue, which has been underway even if with difficulties in the institutional system, there also exists a coordination problem. Some respondents stated that while there has been an effort by the National Strategy for Fighting Corruption and Money Laundering (ENCCLA), coordination problems still persist. According to the interviewees, the ENCCLA offers an important forum for exchanging experiences and expertise. The ENCCLA is a forum for creating common strategies to the system of institutions, but struggles with the authoritative coordination of actions within this system of institutions. Respondents reported that ENCCLA is successful in formulating strategic objectives, grounded in joint studies and in debating common problems. As stated by the respondents, legislative innovations were produced within the ENCCLA as well as the discussion of several issues common to the system of accountability institutions ${ }^{4}$.

Respondents reported that the interaction between institutions and the coordinated integration of actions are crucial to the workings of the system. However, the coordination issue is transversed by the information problem. According to some respondents, the intensity of the interaction among institutions of the system of accountability decreases insofar that institutional dispute prevails not only within the political field, but also in the production and processing of information. Most respondents acknowledged the need for information sharing. However, they also acknowledge that information is an element of power.

In this assertion, information dispute establishes difficulties when it comes to coordinating the activities of the system of accountability institutions. Moreover, contrary to what the respondents stated as being the difficulties toward politics, they realize that an institutional control of public administration cannot abstain from being inserted within power relations. Information empowers institutions of the accountability system, rendering their actions to become political, beyond the scope of administrative procedures. The ENCCLA plays a primary role in being a forum for the deliberation of strategic priorities. However, according to the respondents, the

$4 \quad$ The National Strategy for Fighting Corruption and Money Laundering is an initiative of the Federal Ministry of Justice, representing a debate forum for creating strategies for fighting corruption and money laundering in Brazil. The ENCCLA brings together circa 60 agencies directly or indirectly involved in fighting corruption. It is organized by an annual Plenary Meeting, which brings together all agencies, in order to discuss the work conducted over the year and to decide on actions for the following year; several Workgroup meetings, formed by participating or guest agencies, with the objective of conducing the Plenary's deliberative actions; and bimonthly meetings of the Integrated Administration Office - IAO, which consists of a group of 25 ENCCLA participating agencies with the objective of monitoring the implementation of actions, and to suggest actions and recommendations to be discussed in the Plenary Meetings. 
ENCCLA has not yet been able to take on the coordination of the system of accountability institutions, and thus the lack of coordination hinders any institutional cooperation. Instead, we find political disputes among institutions embedded with the responsibility of controlling public administration and fighting corruption.

Within this context, one of the main findings explaining the occurrence of procedural inconsistency within the system of accountability institutions lies in the fact that a political dispute exists, motivated by public opinion. Corruption and administrative irregularities leads to public attention, which in turn leads to an intense dispute among institutions seeking recognition and therefore, a substantial symbolic power. This symbolic power is responsible for introducing a procedural inconsistency within the system of accountability institutions, through which by knowing that competences are complementary, no activity sequencing occurs nor the necessary attention is given to elements traversing the interaction among institutions.

As reported by respondents, despite the efforts in institutional coordination and cooperation, there is little coordinated effort capable of ensuring the full development of the institutions in the accountability system. The creation of incentives for coordination is vital for establishing cooperation, even in a context of dispute for symbolic power. In this case, the process of institutional change collides with the issue of activity sequencing in such a way that, despite the information raised in the Sweepstakes Program, the ineffective cooperation of institutions of the accountability system hampers the necessary continuity of control actions and the fight against administrative irregularities and corruption. Without common efforts from institutions of the accountability system, there will be little progress in tackling the government's quality problems and corruption.

\section{Final remarks}

The Brazilian case shows that an analysis of the institutional development process must address not only an internal approach on institutions, but also attend to a broader process encompassing systemic changes in the institutional ecology. Without an understanding of this ecology of institutions, based on their procedural flow and the strategic behavior of actors, it becomes impossible to fully comprehend the performance of the institutional system.

Regarding the case study of accountability institutions in Brazil, evidence shows that procedural ecology manifests itself as a sense of competition among the systemic elements, i.e. among the institutions of the accountability system. The conflict logic is the fact that institutions compete for the procedures of other elements of the system and do not respond to demands that are internal to the system itself. In this case, the concept of procedural ecology leads us to the fact that the interaction between the accountability system elements causes the closing of each institution in its own operational base.

Although there is common knowledge among the staff about the necessity of cooperation and institutional coordination, the result indicated by the evidence described above directs the analysis to the fact that there is a dispute over control procedures and instrumental use of the information created, without there being any interaction process grounded in open exchanges and robust procedures to ensure the fluidity of those systemic exchanges. 
The result is therefore that the process of institutional change collides with systemic processes changes, whereby inside the system of accountability of institutions in Brazil there is a strong process of differentiation between institutions, on the one hand, without any opening of symbiotic exchanges of processes and information, on the other. It follows that the procedural ecology of the system of accountability institutions in Brazil did not advance the systemic variables change and so the conflict between the institutions undermines their interdependence, complementariness, sequencing of actions and the fluidity of the set of institutions that compete for perceptions external to the system itself.

The systemic dimension is jeopardized because there have been no changes in the procedural ecology of institutions, creating a dispute scenario for procedures and political conflict among institutions and affecting, in turn, the entire set of results. In that sense, the systemic dimension of institutional change is critical in determining the change process as well as its directions.

The variables of the process of institutional change need be considered, in which the interactions between institutions matter not only for the results, but also for internal processes, rules and organizational routines inherent to the institutions. Thus, understanding the systemic factors of institutional development involves considering the following factors, in the light of the procedural ecology concept: (1) - the flow and sequencing of processes internal to the system; (2) - the stances of the agents in regard to the institutional interactions; (3) - the establishment of joint organizational goals for the system; (4) - the control and use of information by the system elements; (5) - the response to internal situations and demands on the part of each of the elements that make up the system; (6) - the response to external situations and demands on the part of each of the elements that make up the system.

Considering these analytical factors, the process of change can be understood in terms of the interdependence of institutions, when appropriate, and how those factors affect the institutional development process, favoring either change or the status quo. Systemic variables thus influence institutional incrementalism, so that the agents still prefer incremental changes in routines and processes for their institutions in response to endogenous and exogenous environmental factors. However, this incrementalism may result either in a differentiation and greater closing of each of the system elements, favoring institutional conflict, or in an incremental process that is capable, by means of cooperation and coordination of system elements, of driving the process of interdependence, overlapping and complementary institutions. In the latter case, the agents act within systemic structures that promote or inhibit the conflict of institutions, responding to this by producing increments of rules and organizational routines that result in conditions for greater closure or greater opening of the organizations. The direction of these incremental changes in the system matters for the result is because it sets the change of trajectory and patterns of interaction between system elements.

Particularly concerning the system of accountability institutions in Brazil, the institutional development of each institution is verifiable. However, this development process did not lead to systemic changes in the ecology of institutions in such a way to create incentives for institutional cooperation, for the coordination of activities, and for the sequencing of activities within the procedural flow. Likewise, the institutional development process did not lead to reasons to extinguish and to control the political conflict within the system of accountability institutions. The political conflict surrounding Brazil's institutions of the accountability system paralyzes the 
sequencing of activities and establishes a scenario of political struggles for public opinion.

Poor performance, as in the case of the Public Sweepstakes Program, reveals an institutional ecology grounded on political dispute and the uncooperative nature of the accountability institutions, producing a much lower than expected and less effective performance regarding the relational accountability process. In spite of the development process of accountability institutions, systemic ecology and procedural flow reproduce a scenario of accountability deficit.

\section{References}

Abranches, S. H. (1988). "Presidencialismo de coalizão: O dilema institucional brasileiro", en Dados - Revista de Ciências Sociais, vol. 31, nº 1, pp. 5-34.

Anechiarico, F y Jacobs, J. (1996). The persuit of absolute integrity. How corruption control makes government ineffective. Chicago: The University of Chicago Press.

Arantes, R. B. (2011a). "Polícia federal e construção institucional”, en Avritzer, L y Filgueiras, F. Corrupção e sistema político no Brasil. Rio de Janeiro: Editora Civilização Brasileira.

- (2011b) "The Federal police and Ministério Público", en Power, T y Taylor, M. (eds.). Corruption and democracy in Brazil. The struggle for accountability. Notre Dame: University of Notre Dame Press.

Avritzer, L. (2012). "The different designs of public participation in Brazil: Deliberation, power sharing and public ratificatio", em Critical Policy Studies, vol. 6, n 2, pp. 113-127, 2012.

Balbe, R. (2013). Controle interno e o foco nos resultados. São Paulo: Editora Fórum.

Bovens, M. (2007). Analysing and assessing accountability: A conceptual framework. European Law Journal, vol. 13, $\mathrm{n}^{\circ}$ 4, pp. 447-468.

Dimaggio, P y Powell, W. (1983). "The iron cage revisited: Isomorphism and collective rationality in organizational fields", en American Sociological Review, vol. 48, no 2, pp. 147-160.

Doig, A y Mcivor, S. (2003). "National integrity systems. Assessing corruption and reform", en Public Administration and Development, vol. 23, nº 4, pp. 317-332.

Filgueiras, F. (2016). "Transparency and accountability: Principles and rules for the construction of publicity", en Journal of Public Affairs, vol. 16, nº 3, pp. 192-202.

- (2013). "Corrupção e cultura política: a percepção da corrupção no Brasil”, en Telles, H y Moreno, A. Comportamento eleitoral e comunicação política na América Latina. Belo Horizonte: Editora UFMG, pp. 221-258.

Filgueiras, F y Araújo, M. M. (2014). "A política anticorrupção e o marco legal no Brasil”, em Cunha, I. F y Serrano, E. Cobertura jornalística da corrupção. Sistemas políticos, sistemas midiáticos e enquadramentos Legais. Lisboa: Alêtheia Editores, pp. 36-71.

Hall, P y Taylor, R. (1996). "Political science and three new institutionalisms", en Political Studies, vol. 44, no 5, pp. 936-957.

La Porta, R., Lopes-de-Silanes, F., Shleifer, A y Vishny, R. (1999). "The quality of government”, en The Journal of Law, Economics, and Organization, vol. 15, n 1, pp. 222-279.

Leff, N. H. (1964). "Economic development through bureaucratic corruption", en American Behavioral Scientist, vol. 8, n 3, pp. 8-14.

Limongi, F. (2006). "A democracia no Brasil. Presidencialismo, coalizão partidária e processo decisório", en Novos Estudos, n 76, pp. 17-41.

Lindblom, C. E. (1959). "The science of "muddling trough", en Public Administration Review, vol. $19, \mathrm{n}^{\mathrm{o}} 2$, pp. 79-88. 
Loureiro, M. R., Teixeira, M. A. C y Cacique, T. (2009). "Democratização e reforma do Estado: o desenvolvimento institucional no tribunais de contas no Brasil Recente", em Revista de Administração Pública, vol. 43, n 4, pp. 739-772.

Mahoney, J y Thelen, K. (2010). "A theory of gradual institutional change”, en Mahoney, J y Thelen, K. (Eds.). Explaining institutional change: Ambiguity, agency and power. Cambridge: Cambridge University Press.

Mainwaring, S. (2003). "Introduction: Democratic accountability in Latin America", Mainwaring, S y Welna, C. Democratic accountability in Latin America. Oxford: Oxford University Press.

North, D. C. (1990). Institutions, institutional change and economic performance. Cambridge: Cambridge University Press.

Nunes, E. (1997). A gramática política do Brasil. Rio de Janeiro: Jorge Zahar Editores.

O’Donnell, G. (1999). "Horizontal accountability in new democracies", en Schedler, A., Diamond, L y Plattner, M. The self-restraining state. Power and accountability in new democracies. Boulder: Lynne Rienner Publishers.

- (1996). "Uma outra institucionalização: América Latina e alhures", en Lua Nova, no 37, pp. 5-31.

Olsen, J. P. (2017). Democratic accountability, political order, and change. Oxford: Oxford University Press.

Philp, M. (2009). "Delimiting democratic accountability”, en Political Studies, vol. 57, n 1, pp. 28-53.

Pierson, P. (2004). Politics in Time. History, institutions, and social analysis. Princeton: Princeton University Press.

Porto, M. (2011). “The media and political accountability", en Power, T y Taylor, M. (eds.). Corruption and democracy in Brazil. The struggle for accountability. Notre Dame: University of Notre Dame Press.

Przeworski, A y Cheibub, J. A. (1999). "Democracy, elections, and accountability for economic outcomes”, en Przeworski, A., Stokes, S y Manin, B. Democracy, accountability and representation. Cambridge: University Press.

Rezende, F. C. (2009). "Analytical challenges for the neoinstitutional Theories of institutional change in comparative political science”, en Brazilian Political Science Review, vol. 3, p. 98-126.

Rosanvallon, P. (2006). Le contre-democracie. Paris: Seuil.

Rose-Ackerman, S. (1999). Corruption and government. Cambridge: Cambridge University Press.

Rothstein, B. (2011). The quality of government. Corruption, social trust, and inequality in international perspective. Chicago: The University of Chicago Press.

Shleifer, A y Vishny, R. (1993). “Corruption”, en The Quarterly Journal of Economics, vol. $108, n^{\circ} 3$, pp. 681-712.

Speck, B. W. (2000). Inovação e rotina no Tribunal de Contas da União. O Papel da Instituição Superior de Controle Financeiro no Sistema Político-Administrativo Brasileiro. São Paulo: Fundação Konrad-Adenauer Stiftung.

Taylor, M y Praça, S. (2014). "Inching toward accountability", en Latin American Politics and Society, vol. 56, $\mathrm{n}^{\circ} 2$, pp. 27-48.

Taylor, M y Buranelli, V. (2007). "Ending up in Pizza. Accountability as a problem of institutional arrangement in Brazil", en Latin American Politics and Society, vol. 49, n 1 , pp. 59-87. 